\title{
DRY CREEK COPPER PROSPECT FAIRBANKS, ALASKA
}

\author{
by
}

Cleland N. Conwell

Mining Engineer

PROSPECT EXAMINATION 58-16. 67-3A

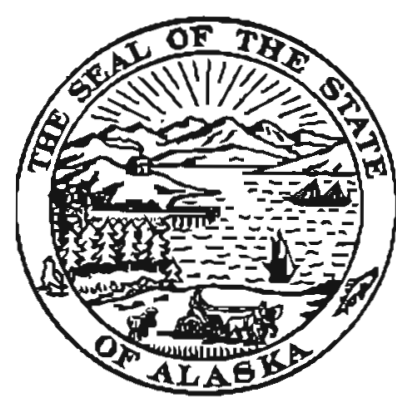




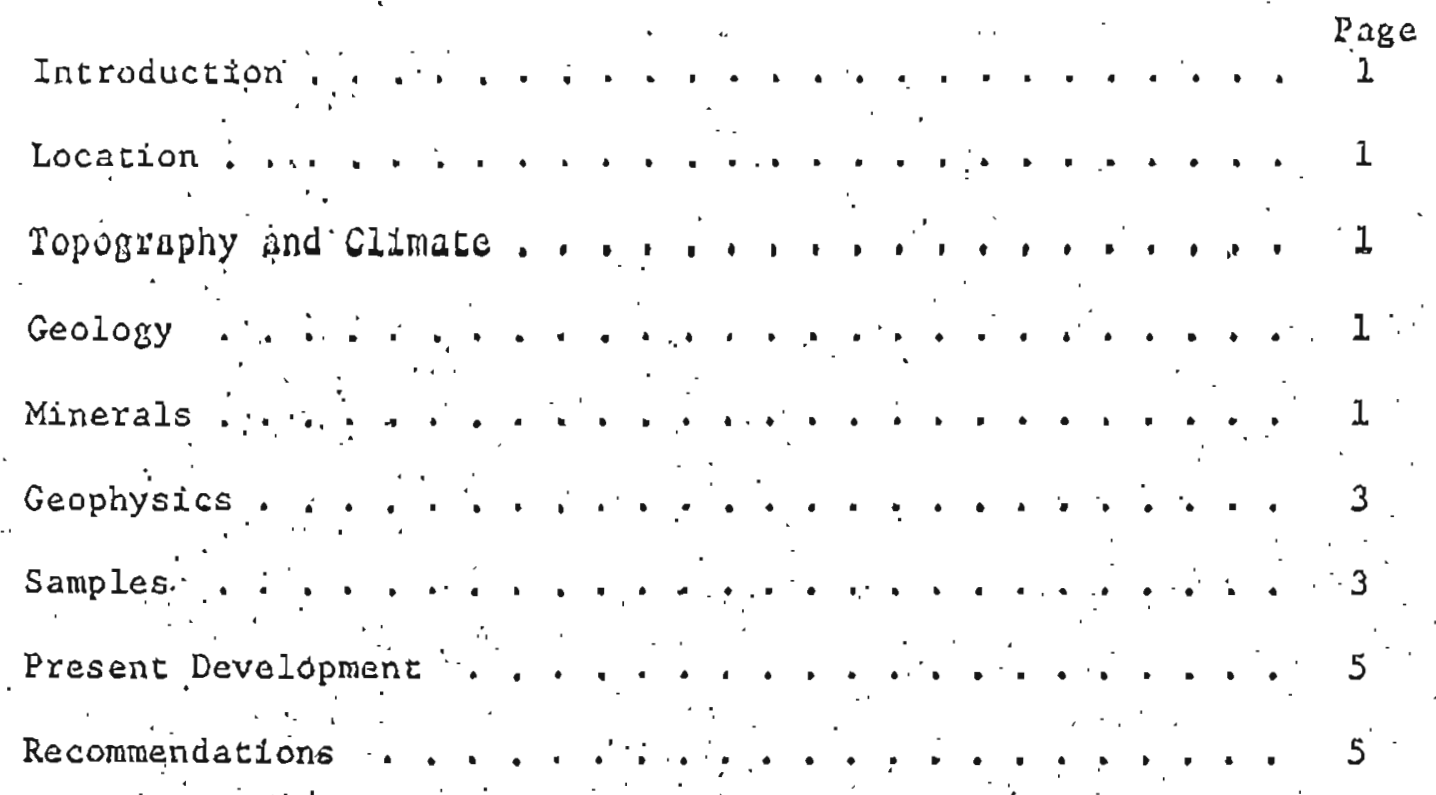

Figures

Area Locarion Map $: . . . . . . . . . . . . . . .22$

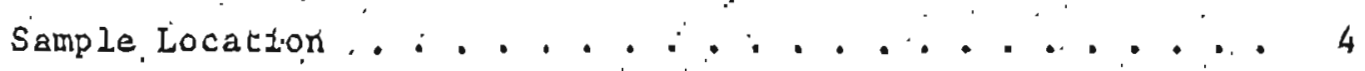

\section{Table}

Laboratory Analysis Report . . . . . . ....... 6

\section{Bibliography}

References Cited ...... . . . . . . . . . . 7 
On June 15, 1972, I mide a bries excimination of mineral slowings. on claims orried by Iob Buzby of 46 Mile Richardson Vighway, Eairbanks, Aiaska. Mr. Burby provided air transportation from Fairbanks to an airstitp on the claims and transportation with an all terrain vehicle to the simplic: locations. The area was visiced again on September 15 , $197 ?$ but snow covered the area and no atcempt was made to do any

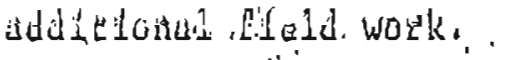

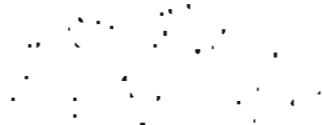

\section{LOCATION}

The prospect is located on Dry Creek about 70 miles southeast of Fairbanks on the norch side of the Alaskan Range in Fairbanks $\Lambda$-i and Healy D-1 quadrangles. It is less chan 30 miles in a direct line from the Alaska Highwa between Fairbanks and Delta Junction, Alaska, and approximacely: 60 miles from the Alaska Railroad at Ferry. (Eigure 1).

\section{TOPOGRAPHY AND CLIMATE}

The prospect is located on low hills north of the very rugged mouncains".of' the Alaska Range. The, climace is arctic. Temperatures vary from $80^{\circ}$ in the summertime to $-60^{\circ}$ in the vintertime. The area should normally be Eree of snow from the first of June to the first of September:

\section{$\therefore \quad$ GEOLOCY}

The area notth of the low hills is covered by recent sediments. The exposed beodrock in all areas examined is a schist. No artempt was made to classify the schist. Wahrhaftig, 1968, has classified the schists of the Alarka Range in the quadrangles immediately west, Fairbanks $(A-2)$ and Healy (D-2).. Pewe, and others,. 1966, have rentatively identified the schist as Totatlanika of Mississippian age on the geologic map of the Fairbanks quadrangle.

\section{MINERALS}

The metal minerals that were identified in hand specimens included the lead minerals, galena and cerussice, and the copper minerals chalcocite, chalcopyrite, azurite and malachice. Galena was exposed at the surface with very little alteration to cerussite. The dark conper suiphtdes were difficult to decermine in a hand specinen. The presence of copper was easily decected by the blue and green. minerals, azurite and malachite. The high copper values in samples 10 and 11 were used as an indicator.of chalcocite. 


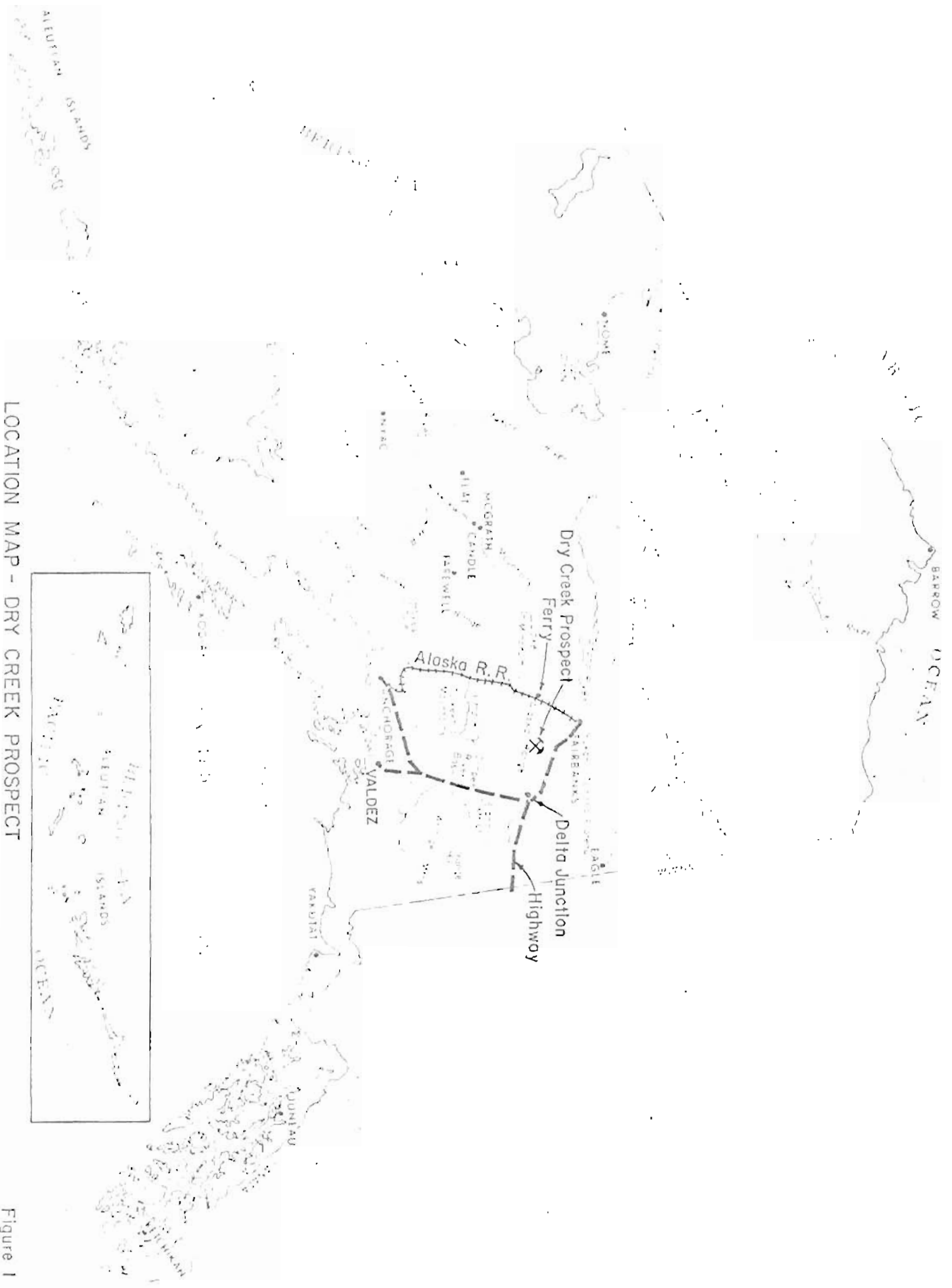


CEOPHYSICS

The Mlaska Division of Geological and Geophysical Surveys compleced an airborne magneconeter survey of the Fairbanks. (A-1) quadrangle in 1971. The contours have been plotted on the rigure 2. The magnetic. higil may indicace an intrusive rock north of the sample locations. The mignetic lorv may indicate the intrusive dips to the south and is under cilc nirieralized irea.' This may be signiflcant as representing a source fQt mineralization in the ovarlaying schist.

\section{SAMPLES}

$\Lambda$ total of 12 samples vere collected in the area. The approximate location is indicated on Figure 2. All samples were analyzed by the Division Laboratory in Fairbanks and the analyses are included with this report as Table 1. The samples are described as follows:

Sample 1. A copper showing under water in a trench imediacely northwest of the airport. It was difficult to get a good channel sample of this area because of water.

Sample'2. Astreak of galena, approximately 8 inches wide, that $\therefore$ is exposed. in two cuts, for a horizonial distance of about 50 feet.

Sample 3a. Copper veinlets in schist.

Sample $3 b^{\prime}:$ Copper veinlers in schist about 10 feet away from $3 a$.

Sample $4 . \because$ A chip sample, 4 to 5 feet wide on the back of an old cunnel.

Sample 5:: A chip sample on the same structure in a dozer cut.

Sample 6. $\therefore$ A 12-inch channel sample of copper mineralization dissiminated in the schist.

Sample 7. MIneralization in quarcz yeins in the schist.

Sample. 8. "A copper mineral dissiminated in veinlets through the schist over a 4-foot outcrop.

Sample 9.' Ditto No. 8, about 20 feet souch along the same outcrop.

Sample $10 \%$. $\Lambda$ selected piece containing copper intnerals. The - outcr layer minerals are azurite and malacite. On - a.fresli surface chalcocite appears to be present.

Sample 1i: A 2-inch veinlet of same material as No. 10 consisting $\therefore \quad \therefore$ "of several chips taken laterally along the veinler.

Sample 12. A gossan zone, poorly exposed but probably 3 to 4 . $\therefore \quad \therefore$ feet wide. 


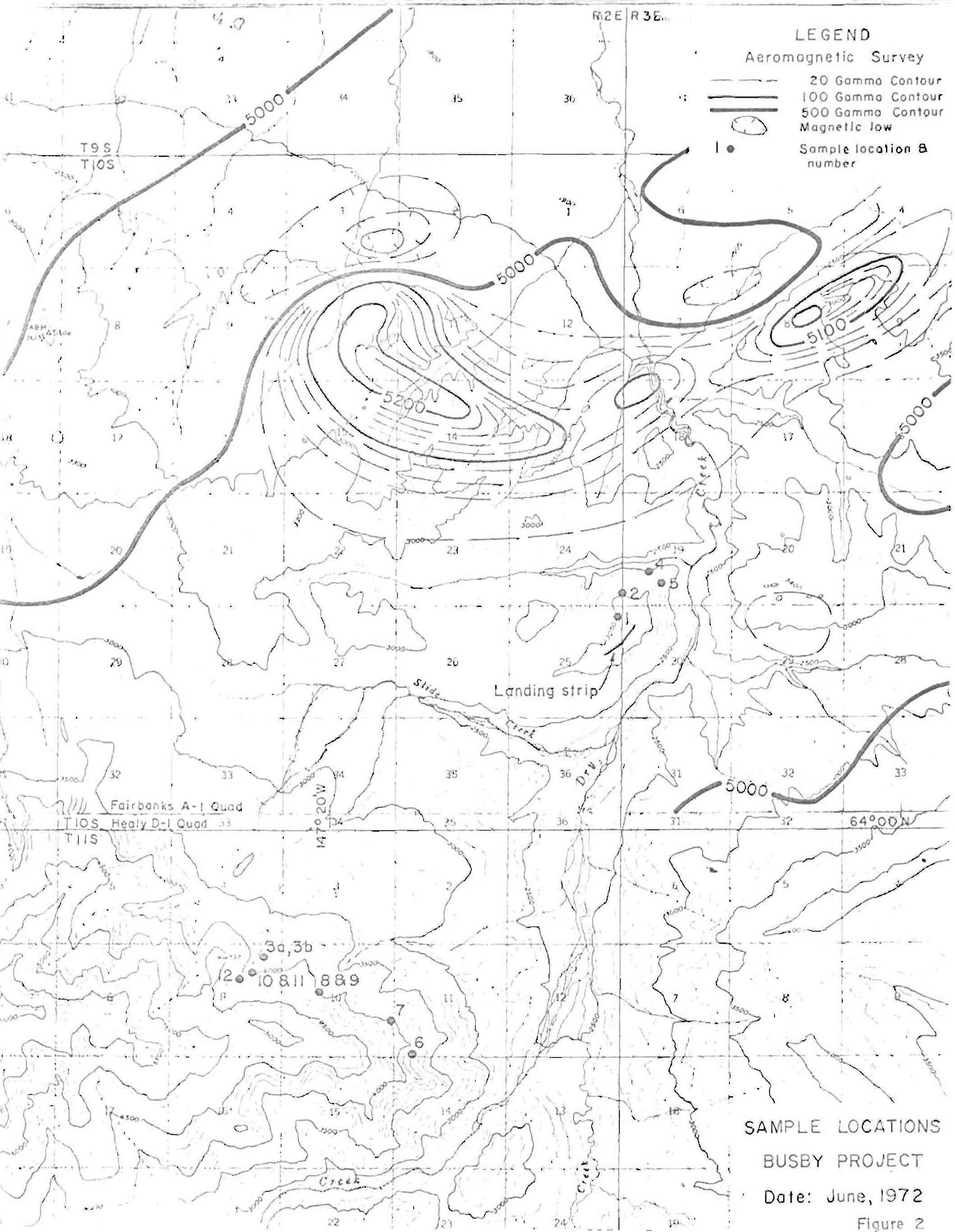




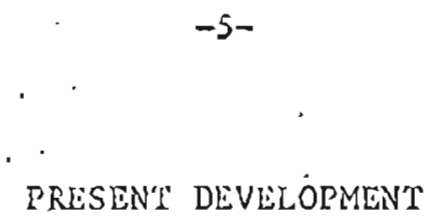

M: Buzby has exposed copper mineralization in several cucs near che landing sirip. A shorc cunnel had been driven many years ago at simple location.4. Mr. Buzby Earther exposed this structure by dozer cuts near sample location 5 . At the time of examination the galena streak vas exposed in 2 dozer culs. After the examination Mr. Buzby worked along the vein and reportedly mined abour 14 tons. of lead ore which should analyze about the same as sample 2 .

\section{RECOMENDATIONS}

The widespread-occurrence of copper mineralization and the high silver value of the galena warrant additional work on this prospect. The recomimendations are divided as separate for the lead and the copper prospects :

The galena vein is small. The value of lead, silver and gold is sufficient to consider this vein for a small mining operation of direct shipping ore. On this basis the following recommendations are madé: $:$.

1. Continue to explore the vein along the strike by open cuts. . The curs should be closely spaced or even a trench on the vein.

2. If the vein ican be traced down the slope of the hill; explore at a vertical depth of at least 100, by a ditit along the vein.

3:" Save the ore that can be recovered, on the surface and drifting, by hand sorting for a' shipment.

4: Diamond drilling on a small vein of this type is not recommended. .

The copper mineralization covers a large area (abour 6 square miles). The areal extent of copper mineralization and grade is sufficient to warrant addi.tional exploration. Additional exploration should include:

1. Accurately map and locate each showing of copper mineralizacion.

2. Sampie and map each area of copper mineralization separately.

3. Examine and map the fracture patterns on good. rock exposures in the area covered by tigure 2 .

4.': Investigate the trend indicated by the magnetic high to - locate an intrusive rock.

5. If an incrusive rock is located, evaluate the intrusive as a possible source for copper mineralization. 
DM-11

Rev. $10 / 67$

Report No.

2873

STAYE OF ALASKA

- Oeporlmont of Nelurol Rosources

Date of Report July $31, \ldots 12$

DIVISION OF MINES AND GEOLOOY

'Box C. Collogo, Alosko 99701

\section{LABORATORY ANALYSS REPORT}

For Cle Cons:e LL.$$
\text { iNumbor of samolos }
$$

Work Donu:

llor Anolyst

sou bolows
A. $\lambda$-roy llourusconco quani. $\square$ : sominquant.

i. $\lambda$-roy dillroction $D$

C. Spritrojraphic 'quónt

D. Spcilroscopic $\square$.
Adoross Division of Geological Survey - Collage

Dolo Somplo Rocoivod GL26ist

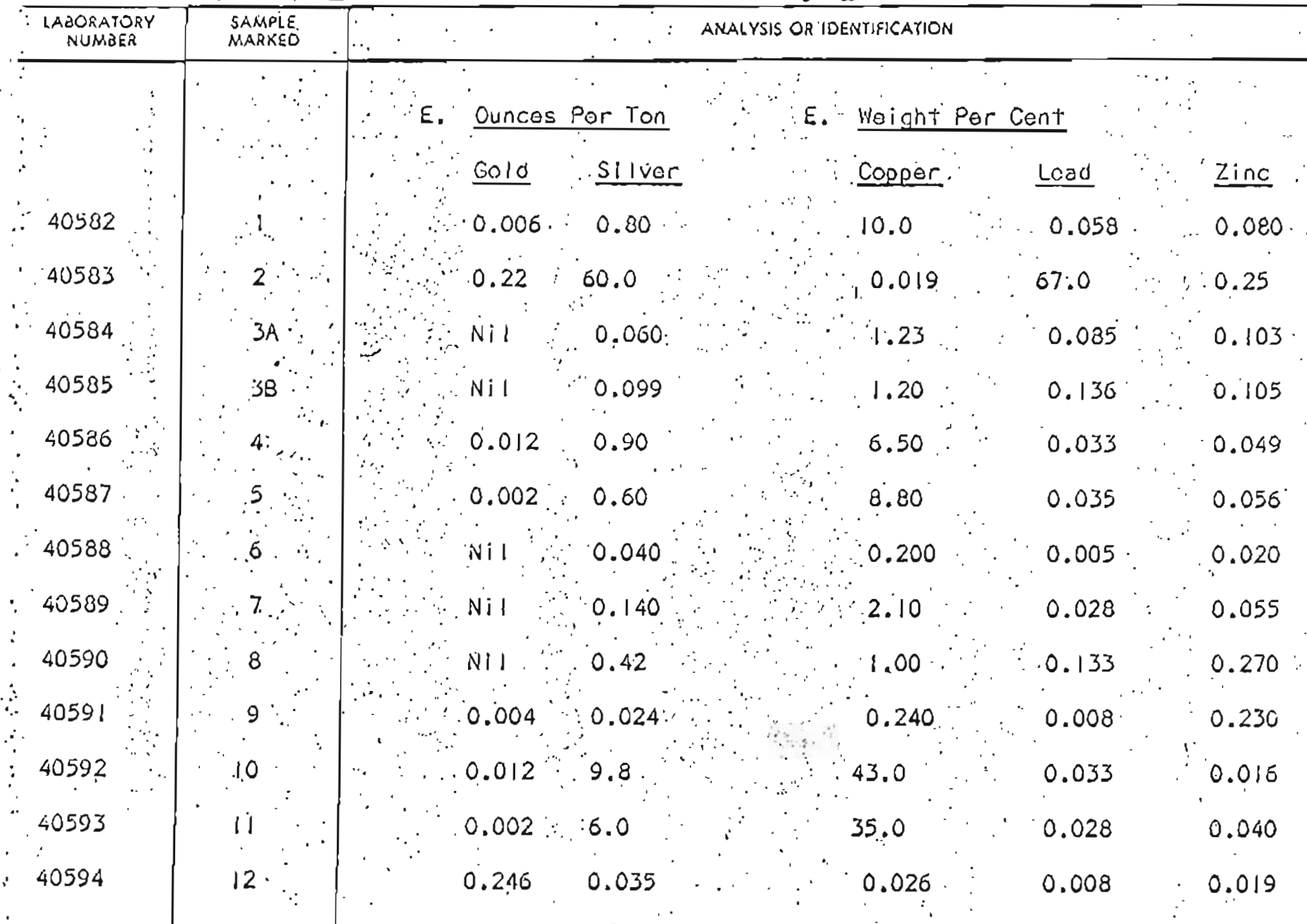

Your somple(s) was tentad for radio-" assivity rio rienlficont radioaclivity ivas doiociab.
Nil goidimoans less than 0.001 troy ounces per ton. - Accuracy of the atomil absorption analysls for gold, silver, copper; lead, and zinc is $\pm 10 \%$ of the reporteo vaive.

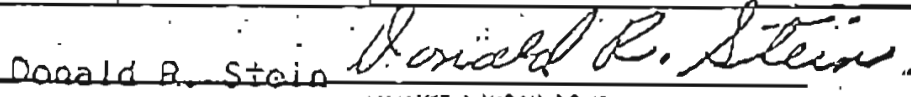

E. Alomic absorplion quant. $\square$ somi-quant. $\square$

F. Firo assay $\square$

H. Othor (Spocify) $\square$ 


\section{REFER̈LNCES CI'IED}

Alaska Geological Survey, 1972, Aeromagnetic Survey, East Alaska Range, Healy (D-1) quadrangle Alaska, Alaska Department of Natural Resources, Division of Geological Survey, Scale 1:63,360

Pewe, T: i., Wahrhaftig, C., Weber, F., 2966, Geologic. Map of the Fairbanks Quadrangle, Alaska; Miscellaneous Geological Investlgations; U. S., Geologicai Survey Map I-45S

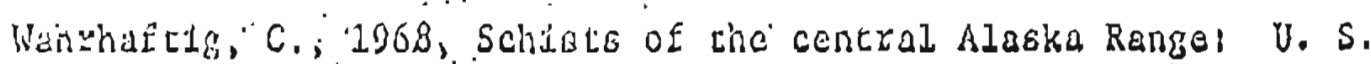
Geological Survey Buli. 2254-E, P. El-E22 